\title{
Diversity and distribution of antennal sensilla in Glossosomatidae in comparison with other basal families of caddisflies (Insecta: Trichoptera)
}

\author{
MIKHAIL YU. VALUYSKIY ${ }^{1,2^{*}}$, STANISLAV I. MELNITSKY ${ }^{1,3} \&$ VLADIMIR D. IVANOV ${ }^{1,4}$ \\ *Corresponding author: "Ephingonaepiopsis@gmail.com \\ ${ }^{1}$ Department of Entomology, Faculty of Biology, St. Petersburg State University, Universitetskaya emb., 7/9, St. Petersburg 199034, \\ Russia. \\ ${ }^{2}$ !"sphingonaepiopsis@gmail.com, @ ittps://orcid.org/0000-0001-9493-3626 \\ 3 "=simelnitsky@gmail.com, @ichttps://orcid.org/0000-0003-4535-1886 \\ 4 "=v-ivanov@yandex.ru, (1) https://orcid.org/0000-0003-3294-4965
}

\begin{abstract}
Structure and distribution of antennal sensilla in 15 species of Glossosomatidae were studied with SEM and compared to available data for species in the families Philopotamidae (16 species previously studied) and Rhyacophilidae (25 species previously studied). Comparative analyses led to 8 different sensillar types being identified among the glossosomatids: long trichoid, curved trichoid, chaetoid, styloconic, coeloconic, mushroom-like pseudoplacoid, coronary, and Böhm's bristles. Diversity of sensilla in Glossosomatidae is lower than reported for Rhyacophilidae and comparable to Philopotamidae. A coeloconic sensillum, unique to Glossosomatidae was identified but shows no species specificity. Distribution of most sensillum types resembles that seen in the other families: There are 2 tiers of sensilla and 4 types of distribution patterns, namely specific, non-specific, fixed, and grouped in sensory fields. Comparisons of Glossosomatidae with other Trichoptera families and data on lower Lepidoptera groups indicate a putative ground plan for antennal sensory structures among Amphiesmenoptera. In contrast, comparative data indicate a significant difference between Amphiesmenoptera and Mecoptera, a member of the sister group to Amphiesmenoptera.
\end{abstract}

Keywords: sensory structures, ultrastructure, sensilla location

\section{Introduction}

Antennal sensilla of Amphiesmenoptera are important in sensory reception and thus behavior and communication of these insects. Antennae of Trichoptera and Lepidoptera often bear a large number and variety of sensilla, presumably involved in olfactory and mechanical reception (Chapman 1998; Sinitsina \& Chaika 2006,). Given the variety of terms applied to various sensilla types, determination of homologies among them is often difficult, especially for the peculiar types such as pseudoplacoid sensilla (Ivanov \& Melnitsky 2011). The ground plan of Trichoptera antennal sensory equipment still remains unclear. Comparison of sensillar structure and location in representatives of basal families of Trichoptera and Lepidoptera, considered sister taxa among the Amphiesmenoptera, may elucidate the ground plan.

Structural data on antennal sensilla in Amphiesmenoptera are available at present from published studies on a considerable number of families. However, most of these studies on sensory structures involve only one species of any particular family. However, the structure of antennal sensilla has been well-studied for several species of Phryganeidae, Limnephilidae (Ivanov \& Melnitsky 2011), and Molannidae (Melnitsky \& Ivanov 2016) (Trichoptera), and was reviewed briefly for a number of other caddisfly families by Ivanov and Melnitsky (2016). Scattered data are available for Lepidoptera in families Micropterigidae (Faucheux 1997), Agathiphagidae (Faucheux 1990), Eriocraniidae (Larsson et al. 2002), Lophocoronidae (Faucheux 2006), Cossidae (Liu et al. 2014) and several other families (Sinitsina and Chaika 2006). Males in Amphiesmenoptera are responsible for female finding in mating, using their antennae to receive pheromone stimuli, hence the male antenna are more interesting for studies of receptors. Diversity of antennal sensilla in males is higher than in females (Wells 1984; Melnitsky \& Ivanov 2016). Recent comparative data on the sensillar structure and 
distribution in Rhyacophilidae (Valuyskiy et al. 2017) and Philopotamidae (Melnitsky et al. 2018) shows considerable diversity within families. Further studies on Trichoptera representatives might expose interspecific modifications in antennal sensory suite.

The family Glossosomatidae includes more than 660 described species. Once included as a subfamily in Rhyacophilidae (Martynov 1934), based on significant similarity of the adult stages (although larvae differ considerably), it is now divided into 4 subfamilies: Agapetinae Martynov 1913; Dajellinae Ivanov et Melnitsky 2006; Glossosomatinae Wallengren 1891; and Protoptilinae Ross 1956. Glossosomatidae and Rhyacophilidae are both considered at the base of Integripalpia branch in the phylogenies created with traditional (Ross 1967; Ivanov \& Sukatsheva 2002) and molecular (Kjer et al. 2002; Holzenthal et al. 2007; Kjer et al. 2016) methods. The first glossosomatid fossil (Dajella tenera Sukatsheva 1990) is known from the late Jurassic (Ivanov \& Melnitsky 2006), thus belonging one of the most ancient Trichoptera families surviving to recent times, in addition to Philopotamidae (Wang et al. 2009) and Rhyacophilidae (Nicholson et al. 2015). Comparative studies of larval antennae (Frania \& Wiggins 1997) show the structure of the larval antennae in Glossosomatidae to be the most plesiomorphic among all Trichoptera families. Given this, we postulated that a study of the diversity and arrangement of antennal sensilla on the antennae of adult members of the family Glossosomatidae and comparison with other families could be informative in our search for the probable ground plan for Trichoptera antennae.

Our analysis of data obtained from Glossosomatidae and other 'basal' families of caddisflies (Rhyacophilidae, Philopotamidae) is supplemented by material from outgroups: Lepidoptera (Micropterigidae, Eriocraniidae) and Mecoptera (Panorpidae, Bittacidae, Meropeidae, Nannochoristidae, Boreidae). Some of the data on these outgroups is original, and some is taken from published literature: Micropterigidae (Faucheux 1997, 2004), Eriocraniidae (Larsson et al. 2002), and Meropeidae (Friedrich et al. 2013). More comprehensive data from our studies for Mecoptera will be published elsewhere.

\section{Material and methods}

\subsection{Studied species}

Males of 15 species of Glossosomatidae were studied, selected to represent two Glossosomatidae genera, Agapetus and Glossosoma, and within these, 2 and 3 subgenera, respectively: Agapetus (Agapetus) bidens McLachlan 1875 (Kazakstan), A. (A.) caucasicus Martynov 1913 (Caucasus), A. (A.) kirgisorum Martynov 1927 (Kazakstan), A. (A.) jakutorum Martynov, 1934 (Siberia), A. (A.) nimbulus McLachlan 1879 (Europe), A. (A.) ochripes Curtis 1834 (Europe), A. (A.) sibiricus Martynov 1918 (Siberia), and A. (Synagapetus) inaequispinosus Schmid, 1970 (Far East of Russia); Glossosoma (Synafophora) intermedium (Klapálek 1892) (Siberia), G. (S.) minutum (Martynov 1927) (Kazakhstan), G. (S.) dulkejti (Martynov 1934) (Siberia), G. (S.) angaricum (Levanidova 1967) (Siberia), G. (Lipoglossa) shugnanicum Ivanov 1992 (Tadzhikistan), and G. (Glossosoma) dentatum McLachlan 1875 (Tadzhikistan); within subfamily Protoptilinae one species was selected: Padunia adelungi Martynov 1910 (Siberia). As outgroups we also studied Micropterix aruncella Scopoli 1763 (Lepidoptera, Micropterigidae) (Caucasus), Eriocrania semipurpurella Stephens 1835 (European Russia), and 4 Mecoptera species: Panorpa communis Linnaeus 1758 (Panorpidae) (Europe), Bittacus cirratus Tjeder 1956 (Bittacidae) (Far East of Russia), Nannochorista andina Byers 1989 (Nannochoristidae) (Chile), and Boreus westwoodi Hagen 1866 (Boreidae) (Europe). Data on previously studied 25 species of Rhyacophilidae and 16 species of Philopotamidae were compared to currently obtained information.

\subsection{SEM, sensilla count and measurements}

Images of antennal structures were obtained using scanning electron microscopy (Jeol NeoScope JSM-5000 microscope), then processed to derive data for comparison. Making preparations, observing the antennal surface, measuring the sensilla and counting their number were performed following a standardized procedure as used by Valuyskiy et al. (2017) and Melnitsky et al. (2018). Insects used in the study were obtained from collections of the Department of Entomology, St. Petersburg University, and Zoological Institute, Russian Academy of Sciences, and stored in 70\% ethanol. Dissected antennae from 1-5 specimens for each species were dried and mounted on microscope holders for subsequent gold coating. All antennal segments were pho- 
tographed at a magnification of 600X. The SEM graphic digital files were edited using graphics software and quantitative parameters of sensilla distribution were evaluated using the SEM data. Counts of the number of sensilla, as well as measurements of segments and sensilla, were performed using ImageJ 1.50 (https://imagej. nih.gov/ij/). Statistical analyses were executed with RStudio 1.0.143 software. Mann-Whitney tests were applied and corrected for multiple comparisons for selected species with the null hypothesis of no significant difference between species; the probability level, set at $\mathrm{p} \leq 0.05$, shows no differences, as expected.

\section{Results}

\subsection{Diversity of sensilla in Glossosomatidae}

All studied species have a non-unique type of sensilla known as Böhm's bristles on the scapes and pedicels. These sensilla are peg-shaped, $15 \pm 1.5 \mu \mathrm{m}$ long, found on most of the studied species of insects, and therefore not a focus of the current study.

Apart from Böhms bristles, seven types of antennal sensilla were recognized on antennal flagellomeres in the studied species of glossosomatid caddisflies, usually nested among a dense scatter of microtrichia. These sensilla types are long, grooved trichoid sensilla; shorter, curved trichoid sensilla; chaetoid sensilla; pseudoplacoid sensilla; styloconic sensilla; coeloconic sensilla; and coronary sensilla. The size of any particular type of sensilla varies slightly among different species of a family.

Long trichoid sensilla (lts, Figs $1 \mathrm{~A}-1 \mathrm{D}, 1 \mathrm{~F}$ ) are about $40 \pm 1.5 \mu \mathrm{m}$ long and have typical structure: Each sensillum is a long seta with a ribbed and poreless surface, the edges near the apex sometimes bearing serration, and the base immersed in an asymmetrically elongate socket. These structures are strongly inclined horizontally towards the antennal apex and, despite their considerable length, do not rise over the surface.

Curved trichoid sensilla (cts, Figs 1C-1E, Figs 2D, 2E) are medium-length in Glossosomatidae (from 13 \pm 0.5 to $16.3 \pm 0.5 \mu \mathrm{m}$ ) and have no visible striae or pores. They form weakly defined sensory clusters located on the ventrolateral surfaces of flagellomeres. These sensory clusters are generally found near the base of an antenna: Curved trichoid sensilla are numerous on the first segment of the flagellum, their numbers slowly decreasing to zero at the 10 th segment.

Chaetoid sensilla (chs, Figs 1A-1E) are short (from $9.5 \pm 0.6 \mu \mathrm{m}$ to $17 \pm 1 \mu \mathrm{m}$ ) and slightly exceed the level of inclined longer trichoid sensilla. These structures are short thickened hairs, each with a hemispherical socket that allows it to rise at a right angle above the surface of the cuticle. Their location in the glossosomatids is less consistent than in other caddisflies, but there is a tendency for these structures to be situated near the base and tip of each flagellomere.

Pseudoplacoid sensilla (mps, Figs 1A, 1C-1F) are mushroom-like in Glossosomatidae. They have curved, often deformed edges and are more or less symmetrical. Their diameters vary from $6 \pm 0.2 \mu \mathrm{m}(G$. intermedium) to $8 \pm 0.3 \mu \mathrm{m}$ (A. bidens). The greatest numbers of sensilla of this type are noted on the basal flagellomeres, these numbers are gradually reduced to a single sensillum on apical flagellomeres. In one species, $A$. bidens, size divergence of pseudoplacoid sensilla into large and small subtypes was noted. Large pseudoplacoid sensilla (lmps, Fig. 2B,) are about $8 \pm 0.3 \mu \mathrm{m}$ in diameter and have a convex surface. Small pseudoplacoid sensilla (smps, Fig. 2B) do not exceed $6.5 \pm 0.1 \mu \mathrm{m}$ and each has a concave surface. Large pseudoplacoid sensilla predominate on the antennal surface of males.

Coeloconic sensilla (cos, Fig. 2A) were found in only one of the species studied, G. (S.) intermedium. These are numerous small cylindrical pegs rising above the surface of the cuticle by less than $1 \mu \mathrm{m}$ and having a very small pore, $2.9 \pm 0.1 \mu \mathrm{m}$ in diameter, in the center of the upper depressed terminal peg surface. They are unevenly scattered on the male antennae from the first to the fourteenth flagellomeres, and are absent in females.

Coronary sensilla (cps, Figs 1A, 1B, 2E) were found on the antennae in A. bidens, A. inaquispinosus, and G. intermedium. The coronary sensilla are from $5 \pm 0.1$ to $7.5 \pm 0.2 \mu \mathrm{m}$ in diameter, in different species. The coronary sensilla in Glossosomatidae are structurally similar to those of Rhyacophilidae, with uneven development of microtrichia only along the border of each sensillum oriented towards the antennal apex.

Styloconic sensilla (sts, Fig. 2C) were found on the same antennae bearing coronary sensilla. The diameter of the base of a styloconic sensillum is $3 \pm 0.2 \mu \mathrm{m}$. These structures are present in a small number only in few regions of an antenna. 

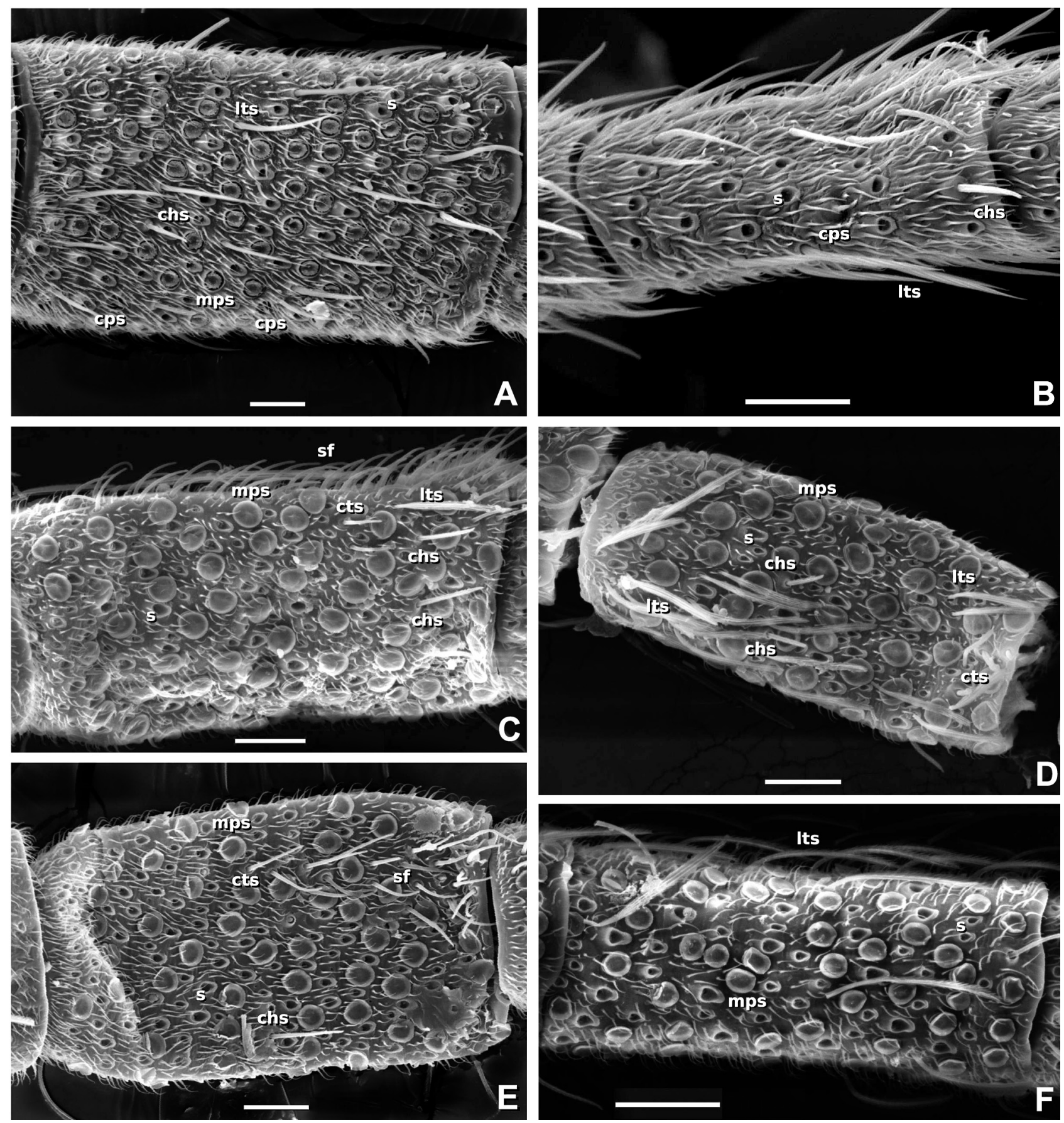

FIGURE 1. Surface structure of antennal flagellomeres of male Glossosomatidae:

1A, 1B, Glossosoma angaricum (Levanidova 1967): 1A, 1st flagellomere, ventral; 1B, preapical flagellomere, ventral. 1C, 1D, Agapetus bidens McLachlan 1875: 1C, 1st flagellomere, left lateral; 1D, 18th flagellomere. 1E, A. jakutorum Martynov 1934, 2nd flagellomere, ventral. 1F, A. nimbulus McLachlan 1879, 2nd flagellomere, ventral.

Abbreviations: $\mathrm{chs}=$ chaetoid sensilla, $\mathrm{cps}=$ coronary sensilla, $\mathrm{cts}=$ curved trichoid sensilla, $\mathrm{mps}=$ mushroom-like pseudoplacoid sensilla, lts $=$ long grooved trichoid sensilla, $\mathrm{sf}=$ sensory field. Scale bars $=20 \mu \mathrm{m}$. 

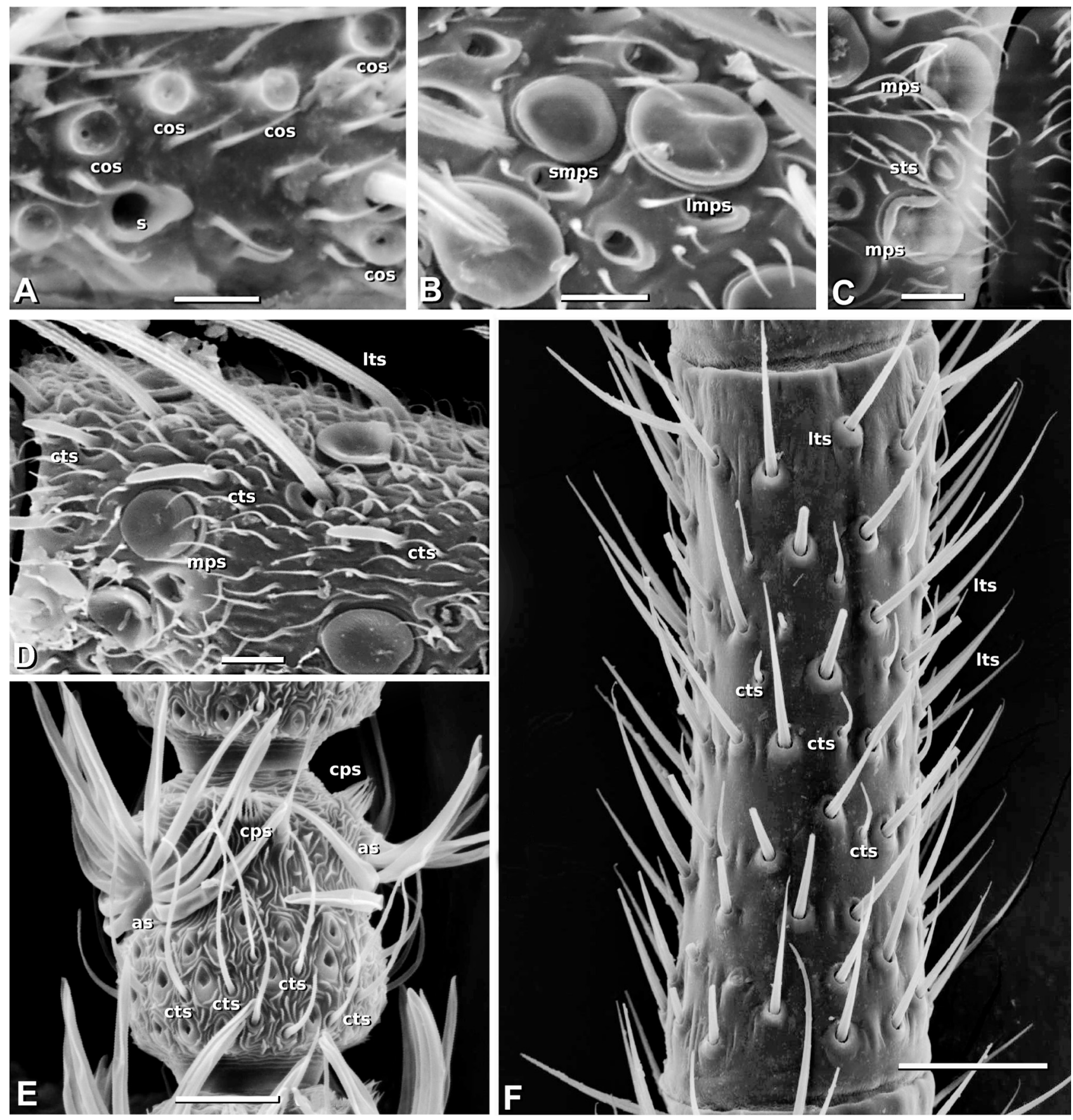

F

FIGURE 2. Surface structure of antennal flagellomeres of male Glossosomatidae (2A-2D), Micropterigidae (2E) and Panorpidae (2F): 2A, Glossosoma intermedium Klapálek 1892, a group of coeloconic sensilla on 2nd flagellomere; 2B, Agapetus bidens McLachlan 1875, 2 subtypes of mushroom-like pseudoplacoid sensilla; 2C, A. nimbulus McLachlan 1879, styloconic and pseudoplacoid sensilla; 2D, Padunia adelungi Martynov 1910, fragment of ventral surface of 2nd flagellomere; 2E, Micropterix aruncella Scopoli 1763, fragment of middle part of antenna, dorsal; 2F, Panorpa communis Linnaeus 1758, 5th flagellomere, ventral.

Abbreviations: as $=$ ascoid sensilla, $\cos =$ coeloconic sensilla, $\mathrm{cps}=$ coronary sensilla, cts $=$ curved trichoid sensilla, $1 \mathrm{mps}$ $=$ large subtype of mushroom-like pseudoplacoid sensilla, lts $=$ long grooved trichoid sensilla, $\mathrm{mps}=$ mushroom-like pseudoplacoid sensilla, $\mathrm{s}=$ socket of detached long trichoid sensilla, smps $=$ small subtype of mushroom-like pseudoplacoid sensilla, sts $=$ styloconic sensillum. Scale bars $=5 \mu \mathrm{m}(2 \mathrm{~A}-2 \mathrm{D}) ; 20 \mu \mathrm{m}(2 \mathrm{E}) ; 50 \mu \mathrm{m}(2 \mathrm{~F})$. 


\subsection{Distribution of sensilla in Glossosomatidae}

Four principal types of sensilla distribution can be found in Trichoptera, including Glossosomatidae. Sensilla exhibiting non-specific distribution are recognized (e.g., long trichoid or pseudoplacoid), the sensilla distributed over the antenna more or less evenly; specific distribution (e.g., curved trichoids, coeloconic, and coronary sensilla) with a single or few sensilla occurring only in certain places that are repeated stereotypically on the surface of each flagellomere; fixed distribution, the sensilla constant in position on different segments; and sensory fields, the sensilla being grouped in patches in certain places on the antenna.

Two principal types of sensilla height above the flagellum surface can be found in Trichoptera, including Glossosomatidae. Chaetoid, long, and curved trichoid sensilla form the higher sensory tier, and the four other sensillar types comprise the lower sensory tier.

Quantitative data on the distribution of antennal sensilla are shown on Figs 3-5. No significant quantitative differences in sensilla were determined among representatives of genus Agapetus and Glossosoma (Figs 4,5 ). The nonspecifically distributed sensilla in these two genera are located unevenly on the surface of each flagellomere. The number of pseudoplacoid sensilla on the ventral surface of flagellomeres is about twice the number on the dorsal surface, and, in contrast, the number of long trichoid sensilla is lower. The more-basal flagellomeres bear ventrolateral sensory fields containing from 20 to 40 curved trichoid sensilla. The number of these sensilla in fields rapidly decreases towards the tip of the antenna and drops to zero after 8-10 flagellomeres. Sensory fields are smaller in all studied representatives of the genus Agapetus than of Glossosoma and sometimes (A. jakutorum) can be found on only one segment. The sensory fields in $A$. bidens are most abundant: In this species they occupy the entire ventral surface, with $40 \pm 3$ sensilla on the 1st and 2nd flagellomeres. However, the size of these fields decreases dramatically on the 3rd flagellomere, and the sensillum count there is $6 \pm 2$.

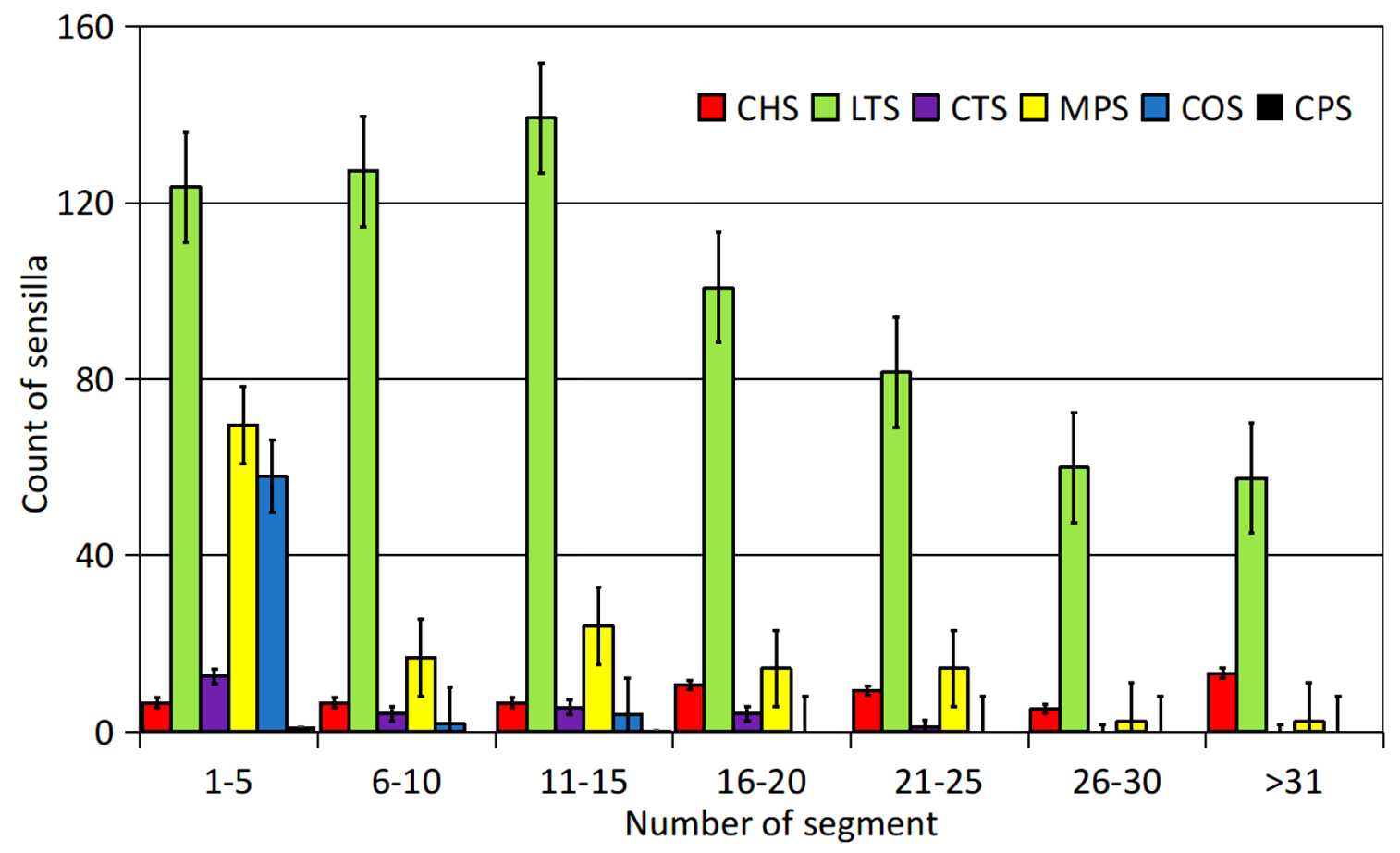

FIGURE 3. Distribution of sensilla on ventral antennal surface in Glossosoma intermedium Klapálek 1892. Types of sensilla: $\mathrm{CHS}=$ chaetoid; $\mathrm{LTS}=$ long trichoid; $\mathrm{CTS}$ = curved trichoid; MPS = pseudoplacoid; $\mathrm{COS}=$ coeloconic; $\mathrm{CPS}=$ coronary.

The number of pseudoplacoid and coeloconic sensilla is higher at the antennal base. There are about 60-70 sensilla per flagellomere on the basal 5 antennal segments and significantly less on others. There is a solitary pseudoplacoid sensillum and no coeloconic sensilla on each terminal flagellomere. Only single coronary and styloconic sensilla are found on several antennal segments. Coronary sensilla in all studied species are located 
occasionally in the middle region of flagellomeres, and the styloconic ones are found near the distal region. Chaetoid sensilla on the proximal flagellomeres form a faintly visible ring of fixed 3-4 sensilla at least $1 / 3$ distance from the base of each flagellomere. Closer to the midpoint of an antenna, another ring of 4-5 sensilla is seen in the distal part of every segment. The apical flagellomere bears up to 13 chaetoid sensilla. This pattern of placement of the antennal sensilla is repeated in all the studied species with minor variations.

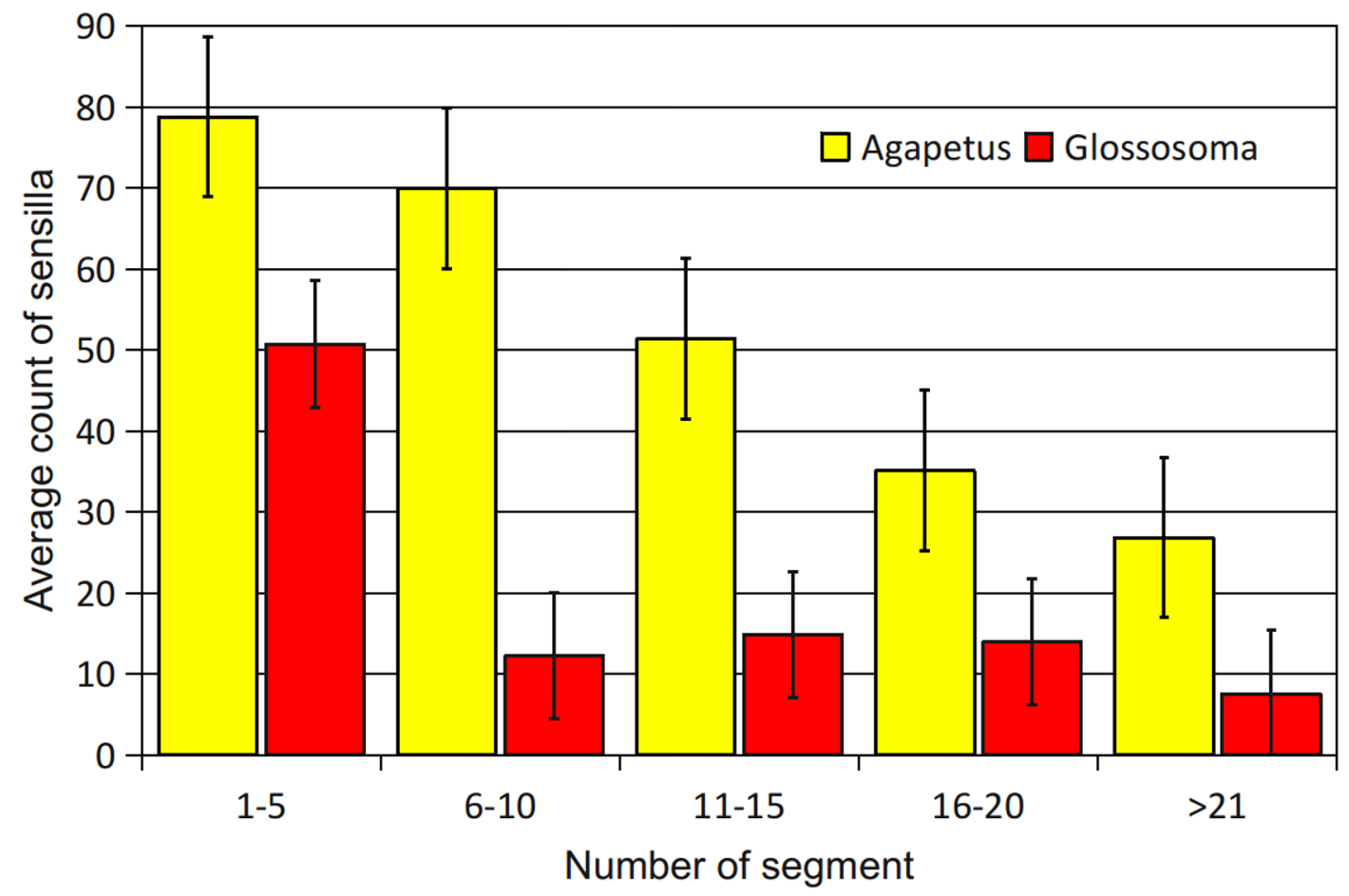

FIGURE 4. Comparison of average counts for mushroom-like pseudoplacoid sensilla in genera Agapetus and Glossosoma.

A decrease in number of sensilla is often correlated with a general decrease in body size, with a proportional reduction in the area of the antennal surface. This is supported by the decrease in the number of sensilla with non-specific distribution when small Glossosomatidae specimens are compared with larger ones. For example, in $G$. intermedium, the basal flagellomeres have a maximal area of $18064 \mu \mathrm{m}^{2}$ and bear about 32 pseudoplacoid sensilla on the ventral surface. In smaller $A$. sibiricus, the antennal area is smaller- $16493 \mu \mathrm{m}^{2}$-and the number of pseudoplacoid sensilla is reduced to 20. The smaller species from a different subfamily, P. adelungi, have the smallest antennal area at $11985 \mu \mathrm{m}^{2}$, with a consequent reduction in the number of pseudoplacoid sensilla to 14 on the ventral surface. However, the size of the antennal surface has almost no effect on size of the sensilla or their relative position on the antenna.

Glossosomatidae have a uniform suite of antennal sensilla. Interspecific differences in the arrangement of individual types of solitary sensilla with a specific distribution do not exceed the intraspecific fluctuations. Statistical analysis (Mann-Whitney test corrected for multiple comparison) demonstrated the sensilla distribution in several species of Agapetus (A. bidens, A. nimbulus, and A. ochripes) to be similar and to belong to the same statistical population ( $\mathrm{p}=0.275 ; 0.275 ; 0.367)$. The selected species of Glossosoma ( $G$. intermedium) shows no difference from Agapetus in this respect $(\mathrm{p}=1)$. Multiple sensilla with a non-specific distribution also do not show significant differences in topology and quantity in different glossosomatid species.

\subsection{Features of antennal sensilla in studied Lepidoptera and Mecoptera}

Study of the antennal surface of Micropterix aruncella does not reveal any significant difference from another species of this genus studied by Faucheux (1997). Micropterigidae moths have eight types of sensilla on flagellum, including long trichoid, chaetoid, short curved trichoid, ascoid (not found in Trichoptera), Böhm's bristles, coronary, pseudoplacoid, and styloconic sensilla. These sensilla types are distributed uniformly along 
an antenna, not showing any prominent decline towards the apex except that chaetoid sensilla increase in abundance on 2 apical segments. Ascoid and coronary sensilla have fixed distributions and quantities. The ascoid sensilla (Fig. 2E, as) are made of ring-like assemblages of basally coalescent curved trichoid units. Each flagellar segment has two ascoid sensilla. The coronary sensilla resemble those of Trichoptera in structure; and they have a fixed position on every segment: Each coronary sensillum is situated between 2 ascoid sensilla in the distal region of the flagellomere.

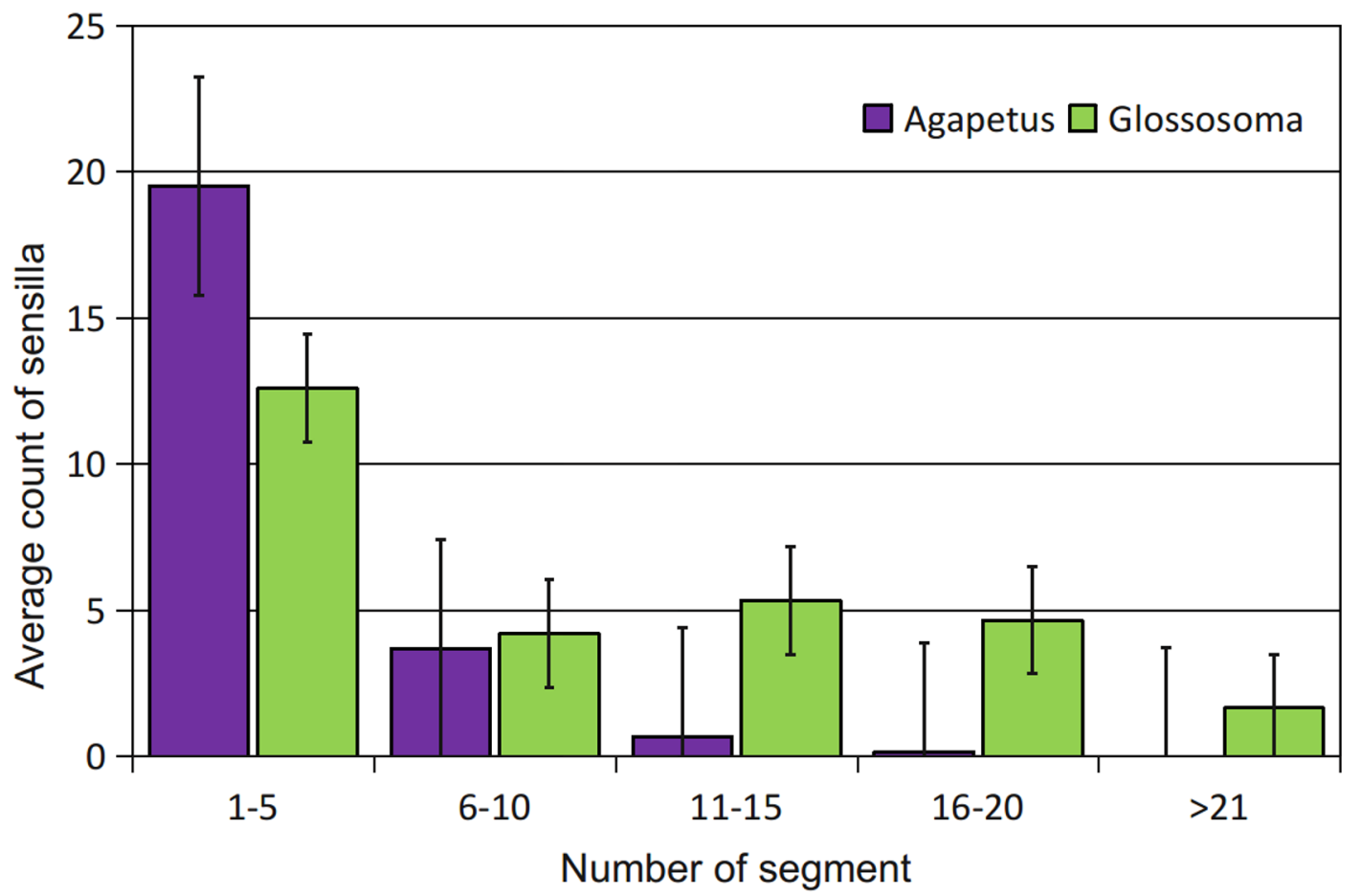

FIGURE 5. Comparison of average counts for curved trichoid sensilla in genera Agapetus and Glossosoma.

Another studied species, Eriocrania semipurpurella, have more caddisfly-like sensory suite with seven types of sensilla. The major structural differences are transformation of pseudoplacoid into auricillic sensilla, also found in Trichoptera family Hydroptilidae according to Wells (1984), and modification of long trichoid sensilla, which became more scale-shaped. Several differences from caddisflies for sensilla distribution on eriocraniid antennal surfaces include placement of sensory fields near the base of each segment and preservation of sensory fields on all flagellomeres to the antennal tip.

Our preliminary study of antennal surfaces in Mecoptera supports the presence of numerous trichoid sensilla as described previously (Ivanov et al. 1975) in Panorpa communis. These sensilla belong to two dimensional tiers, longer and shorter, with nearly equal numbers of each type. Along with these dominant long trichoid sensilla (length $50 \mu \mathrm{m}$; up to 100 per segment), short trichoid sensilla (12-20 $\mu \mathrm{m}$; 60 per segment), and chaetoid sensilla (length $50 \mu \mathrm{m} ; 4-8$ per segment), there are occasional coeloconic (length approximately $2 \mu \mathrm{m}$; diameter 5-7 $\mu \mathrm{m}$; up to 5 per segment) and styloconic (diameter $2 \mu \mathrm{m}$; $1-2$ per segment) sensilla in Panorpidae and Nannochoristidae. In our study, no pseudoplacoid, basiconic, or coronary sensilla were found in Mecoptera. The distribution of sensilla on the flagellar surface of Mecoptera is uniform and non-specific, without clusters or explicit sensory fields and the greatest structural diversity is seen at the medial part of the antenna. In some species (e.g., Panorpa communis) there is a non-uniform distribution of short curved trichoid sensilla, their numbers are increasing on the ventral surface of the flagellomeres and decreasing on the dorsal surface. Böhm's bristles are also present and are similar to those of Trichoptera. In all studied Mecoptera species a few microtrichia can be found on several flagellomeres. Our data stand out with the study of Merope tuber Newmann, 1938 by Friedrich et al. (2013), showing a unique occurrence of sensory clusters on antennae of Mecoptera as cavities with submerged basiconic sensilla. 


\section{Discussion}

The family Glossosomatidae is recognized to comprise four subfamilies and numerous genera and subgenera (Martynov 1934; Morse \& Yang 1993; Ivanov \& Melnitsky 2006; Morse 2018). Despite this taxonomic complexity, our analysis of types and distributions of antennal surface structures did not reveal any significant differences among representative taxa. The only exception we found is in the numbers of sensilla correlated with size of insect and antenna: smaller animals have fewer sensilla. The size of sensilla is smaller in tiny species than in larger ones, but the decrease in size is not proportional and the sensilla in the smallest Protoptilinae are relatively bigger in comparison with larger species of Glossosoma.

Various phylogenies (e.g., Ivanov \& Sukatsheva 2002; Kjer et al. 2002, 2016) place families Glossosomatidae and Hydroptilidae nearby in various combinations; their relationships require revision. According the study of sensilla in Hydroptilidae (Wells 1984), these microcaddisflies have relatively large structural diversity. At least 19 types, or, in terminology accepted here, 8 types with subdivision to subtypes were found on antennal surfaces. The greatest variety is achieved by modification of pseudoplacoid sensilla (4 types of "sensilla auricillica" and 3 types of "sensilla placodea" by Wells), which is also observed in other Trichoptera. Several unique sensilla, such as "rosetted placodea" and "sensilla coelosphaerica" were also recognized in a single species, Hydroptila incertula.

Philopotamidae is the most basal annulipalpian family (Ross 1967; Ivanov \& Sukatsheva 2002) Representatives of its subfamilies, Philopotaminae and the more advanced and younger Chimarrinae studied by us previously, provided data on the structure of the antenna sensory system for 16 species (Melnitsky et al. 2018). It is established that representatives of this family have 8 sensilla types: long and curved trichoid, chaetoid, basiconic, coronary, pseudoplacoid, wide and short styloconic sensilla, and also a Bohm's bristle on the antennal scapus. The total number of sensilla and their diversity is highest near the antennal base.

Family Rhyacophilidae is a widely accepted basal family of Trichoptera with some affinities to Integripalpia (Ross 1967; Frania \& Wiggins 1997; Ivanov \& Sukatsheva 2002). Sensilla of 25 species studied in this family (Valuyskiy et al. 2017) demonstrate great diversity of types (13 types). It appears that further elaboration of pseudoplacoid sensilla has given rise to several structural subtypes and these can be found simultaneously on antennae. In total, five subtypes of pseudoplacoid sensilla and two subtypes of curved trichoid sensilla are to be found in different species of this family. All unique rhyacophilid sensilla are derived from either curved trichoid or pseudoplacoid sensilla. Other sensilla in Rhyacophilidae show close similarity with their counterparts in Glossosomatidae and Philopotamidae. The largest number of sensilla, as in Philopotamidae, are found on the basal antennal segments, but in Rhyacophilidae sensory fields are generally weaker, and form rather mixed clusters including several different sensillar types (Valuyskiy et al. 2017).

Comparing Glossosomatidae with two previously studied families of Trichoptera, we can find significant similarity in structure and distribution of antennal sensilla. The same sensilla types are seen in the ground plan of these families as found in most Glossosomatidae, Rhyacophilidae, and Philopotamidae. These common sensillar types are long trichoid, curved trichoid, mushroom-like pseudoplacoid, styloconic, coronary, chaetoid, and Böhm's bristles. All these types are presumed to be components of the Trichoptera ground plan. Basiconic sensilla probably are not a component of this trichopteran antennal ground plan. In the case of differences, the largest suite of modifications is found among the pseudoplacoid sensilla. All three Trichoptera families exhibit a few peculiar types of antennal sensilla; e.g., Rhyacophilidae have forked, multiforked, dissected, and leaflike sensilla; Philopotamidae have wide and narrow styloconic sensilla; and Glossosomatidae have coeloconic sensilla and two subtypes of pseudoplacoid sensilla, larger and smaller. Differences in these structures including formation of the sensilla subtypes often are found to occur in some species whereas the related species do not have these peculiarities. Modifications of these new structures seem to appear on lower taxonomic levels, from species to species groups or genera. In comparison with other studied families of caddisflies, Glossosomatidae have a rather low diversity of antennal sensory structures.

Studies on antennal cuticular structures suggest significant uniformity of sensilla in the basal Lepidoptera family, Micropterigidae (Faucheux 1997, 2004; and our results). Our data show lower diversity in M. aruncella compared to M. calthella, as found by to Faucheux (1997), a consequence of absence of basiconic sensilla and smaller numbers of pseudoplacoid sensilla. Sensilla found in other lower Lepidoptera (Larsson et al. 2002; Faucheux 1990, 2006, 2007) include trichoid, chaetoid, basiconic, coronary (= coeloconic in Faucheux' terms), 
auricillic, and squamiform types. The "sensilla placodea" described by Faucheux and sensilla auricillica found in a number of other species of Amphiesmenoptera (Wells 1984; Larsson et al. 2002; Faucheux 2006) are apparently the homologs of pseudoplacoid sensilla in Trichoptera; their shape and fine structure appear to be the same. Sometimes these principal types of sensilla form variations or subtypes (Faucheux 2007); this diversification has a parallel in Trichoptera. Pseudoplacoid sensilla in Lepidoptera are not numerous and show a tendency to reduction, disappearing in the most advanced Lepidoptera.

In comparison with Trichoptera and Lepidoptera, the structural diversity of sensilla on antennae of Mecoptera is significantly lower. We could not find any specialized distribution patterns of sensory structures; the only example of specialization is in the occurrence of the cavities with submerged basiconic sensilla in Merope tuber. Simple patterns of sensory structures suggest the less specialized antenna in Mecoptera. We can assume that the antennal structures of scorpionflies belong to biasing type having no specific features of the Amphiesmenoptera antennal surface.

In summary it appears that the ground plan for Amphiesmenoptera includes all the six types found today in members of both orders, Trichoptera and Lepidoptera: the long trichoid and short curved trichoid, pseudoplacoid, chaetoid, coronary and styloconic sensilla. We do not include basiconic sensilla in the ground plan since this type is absent from the basal families of Trichoptera whilst being diverse in Lepidoptera. Our proposed ground plan suggests a uniform non-specific distribution for pseudoplacoid and long trichoid, specific distributions for coronary and styloconic, and fixed distribution for chaetoid sensilla. Initial distribution for curved trichoid sensilla is probably non-specific, but this is still unclear since studied basal Amphiesmenoptera have this sensillum type grouped in sensory clusters.

\section{Acknowledgements}

The authors are thankful to Dr. Pongsak Laudee and the Organizing Committee of the 16th International Symposium on Trichoptera for their kind invitation to attend the Symposium and 2 anonymous reviewers for their questions and corrections. Thanks are due to Dr. Elena Lukashevich for her help with material of Nannochoris$t a$. This work was financially supported by the Russian Foundation for Basic Research (project 18-04-00312), by St. Petersburg State University (SPbU) research grants 1.42.1017.2016, 1.42.1011.2016, 1.42.721.2017, 1.42.722.2017, CONF 20181 and by SPbU Research Park Projects 109-4 and 109-5339.

\section{References}

Byers, G.W. (1989) The Nannochoristidae of South America (Mecoptera). The University of Kansas Science Bulletin, 54 (2), 25-34. https://doi.org/10.5962/bhl.part.19637

Chapman, R.F. (1998) The Insects: Structure and Function. Cambridge University Press, Cambridge, 771 pp. https://doi.org/10.1017/CBO9780511818202

Curtis, J. (1834) Description of some hitherto nondescript British species of mayflies of anglers. The London and Edinburgh Philosophical Magazine and Journal of Science, 3 (4), 120-125, 212-218. https://doi.org/10.1080/14786443408648304

Faucheux, M.J. (1990) Antennal sensilla in adult Agathiphaga vitiensis Dumbl. and A. queenslandensis Dumbl. (Lepidoptera: Agathiphagidae). International Journal of Insect Morphology and Embryology, 19, 257-268. https://doi.org/10.1016/0020-7322(90)90011-D

Faucheux, M.J. (1997) Sensory organs on the antennae of Micropterix calthella L. (Lepidoptera: Micropterigidae). Acta Zoologica, $78,1-8$. https://doi.org/10.1111/j.1463-6395.1997.tb01121.x

Faucheux, M.J. (2004) Antennal sensilla of Sabatinca sterops Turner (Lepidoptera: Micropterigidae). Transactions of The Royal Society of South Australia, 128 (2), 187-194.

Faucheux, M.J. (2006) Antennal sensilla of male Lophocorona pediasia Common 1973 and their phylogenetic implications (Lepidoptera: Lophocoronidae). Annales de la Société Entomologique de France (n.s.), 42 (1), 113-118. https://doi.org/10.1080/00379271.2006.10697456

Faucheux, M.J. (2007) The antennal sensilla basiconica of Nematocentropus cfr. omiensis Hwang, 1965: Contribution to the knowledge of large sensilla basiconica polymorphism in Neopseustidae (Lepidoptera). Annales de la Société Entomologique de France (n.s.), 43 (2), 253-255. 
https://doi.org/10.1080/00379271.2007.10697519

Frania, H.E. \& Wiggins, G.B. (1997) Analysis of morphological and behavioural evidence for the phylogeny and higher classification of Trichoptera (Insecta). Royal Ontario Museum Life Science Contribution, 160, 1-67. https://doi.org/10.5962/bhl.title.53487

Friedrich, F., Pohl, H., Beckmann, F. \& Beutel, R. (2013) The head of Merope tuber (Meropidae) and the phylogeny of Mecoptera (Hexapoda). Arthropod Structure \& Development, 42, 69-88. https://doi.org/10.1016/j.asd.2012.09.006

Hagen, H.A. (1866) Synopsis of the genus Boreus. Entomologist's Monthly Magazine, 3, 132.

Holzenthal, R.W., Blahnik, R.J., Prather, A.L. \& Kjer, K.M. (2007) Order Trichoptera Kirby, 1813 (Insecta), Caddisflies. Zootaxa, 1668, 639-698.

https://doi.org/10.11646/zootaxa.1668.1.29

Ivanov, V.D. (1992) New species of Glossosomatidae and Hydroptilidae (Trichoptera) from Pamir, Hissar and Tienshan Mountains. Aquatic Insects, 14, 223-241. https://doi.org/10.1080/01650429209361488

Ivanov, V.D. \& Melnitsky, S.I. (2006) The morphology of Dajella tenera (Trichoptera, Glossosomatidae): Taxonomic status and evidence for the pheromone communication in the Mesozoic. Entomological Review, 86 (5), 568-575. https://doi.org/10.1134/S0013873806050083

Ivanov, V.D. \& Melnitsky, S.I. (2011) Structure and morphological types of the antennal olfactory sensilla in Phryganeidae and Limnephilidae (Insecta: Trichoptera). Proceedings of the $13^{\text {th }}$ International Symposium on Trichoptera, Zoosymposia, 5, $210-234$. https://doi.org/10.11646/zoosymposia.5.1.16

Ivanov, V.D. \& Melnitsky, S.I. (2016) Diversity of the olfactory sensilla in caddisflies (Trichoptera). In: Vshivkova, T.S. \& Morse, J.C. (Eds), Proceedings of the $14^{\text {th }}$ International Symposium on Trichoptera, Zoosymposia, 10, $224-233$. https://doi.org/10.11646/zoosymposia.10.1.20

Ivanov, V.D. \& Sukatsheva, I.D. (2002) Trichoptera (Phryganeida). In: Rasnitsyn, A.P. \& Quicke, L.J. (Eds.), History of Insects. Kluwer Academic Publishers, Dordrecht, pp. 199-220.

Ivanov, V.P., Ignatiev, A.M. \& Leonovich, S.A. (1975) Fine structure and function of chemoreceptors of Panorpa communis L. Chemoreception in Insects, 2, 77-84. [in Russian]

Kjer, K.M., Blahnik, R.J. \& Holzenthal, R.W. (2002) Phylogeny of Caddisflies (Insecta, Trichoptera). Zoologica Scripta, 31, 83-91. https://doi.org/10.1046/j.0300-3256.2001.00079.x

Kjer, K.M., Thomas, J., Zhou, X., Frandsen, P.B., Scott, E. \& Holzenthal, R.W. (2016) Progress on the phylogeny of caddisflies (Trichoptera). Proceedings of the $14^{\text {th }}$ International Symposium on Trichoptera, Zoosymposia, 10, 248-256. https://doi.org/10.11646/zoosymposia.10.1.23

Klapálek, F. (1892) Trichopterologicky vyzkum Cech v. r. 1891. Rozpravy Ceske Akademie Císaire Frantiska Josefa, Praze, 5, $1-22$.

Larsson, M.C., Hallberg, E., Kozlov, M.V., Francke, W., Hansson, B.S. \& Löfstedt, C. (2002) Specialized olphactory receptor neurons mediating intra- and interspecific chemical communication in leafminer moths Eriocrania spp. (Lepidoptera: Eriocraniidae). Journal of Experimental Biology, 205, 989-998.

Levanidova, I.M. (1967) Data on the fauna of caddis-flies (Trichoptera) from Siberia and Far East. Entomologicheskoe Obozrenie [Entomological Review], 46, 793-798.

Linnaeus, C. (1758) Systema Naturae per Regna tria Naturae, Secundum Classes, Ordines, Genera, Species, cum Characteribus, Differentiis, Synonymis, Locis. 10th Edition, Volume 1: Regnum Animalia. Holmiae [Stockholm], Laurentii Salvii. https://doi.org/10.5962/bhl.title.542

Liu, H., Liu, Zh., Jing, X., Yang, M., Liu, J. \& Zhang, J. (2014) Scanning electron microscopy studies of antennal sensilla of Isoceras sibirica Alpheraky (Lepidoptera, Cossidae). Annales de la Société entomologique de France (n.s.), 50 (3-4), 350-357. https://doi.org/10.1080/00379271.2014.981405

Martynov, A.V. (1910) Les Trichoptères de la Sibèrie et des régions adjacentes. II. La sous f. des Brachycentrinae, les fam. des Molannidae, Leptoceridae, Hydropsychidae, Philopotamidae, Polycentropidae, Psychomyidae, Rhacophilidae et des Hydroptilidae. Annuaire du Musée Zoologique de l'Académie Impériale des Sciences de Saint Pétersbourg, 15, 351-429.

Martynov, A.V. (1913) Contribution to the knowledge of the Trichopterous fauna of the Caucasus [In Russian]. Travaux Laboratoire Zoologie Université Warsaw, 1913 (“1912”), 1-111.

Martynov, A.V. (1918) Sur une nouvelle espèce de la tribu des Apataniini, et quelques autres formes provenant du Pays de Minoussinsk [in Russian]. Annuaire du Musée Zoologique de l'Académie des Sciences de Russie, Petrograd, 22 ("1917”), 45-63.

Martynov, A.V. (1927) Contributions to the aquatic entomofauna of Turkestan. I. Trichoptera Annulipalpia. Annuaire du Musée Zoologique de l'Académie Impériale des Sciences de Saint Pétersbourg, 28, 162-193.

Martynov, A.V. (1934) Caddisflies. Trichoptera-Annulipalpia. I. Opredeliteli po Faune SSSR [Keys to the Fauna of the USSR], Issue 13. Izdatelstvo Zoologicheskogo Instituta Academii Nauk SSSR, Leningrad, 321 pp. [in Russian]

McLachlan, R. (1875) Part 5, Setchatokriliya (Neuroptera). In: Fedtschenko, A.P. (Ed.), Puteshestvie v Turkestan [Travels in 
Turkestan]. Zoogeographicheskiya Izsledovaniya, 2 (8), 1-60, plates 1-4. [in Latin and Russian]

McLachlan, R. (1879) A Monographic Revision and Synopsis of the Trichoptera of the European Fauna. Part 8. John van Voorst, London, pp. 429-500, plates 45-51.

Melnitsky, S.I. \& Ivanov, V.D. (2016) Structure of the antennal olfactory sensilla in the genus Molanna (Trichoptera: Molannidae). In: Vshivkova, T.S. \& Morse, J.C. (Eds.), Proceedings of the $14^{\text {th }}$ International Symposium on Trichoptera, Zoosymposia, 10, 292-300.

https://doi.org/10.11646/zoosymposia.10.1.27

Melnitsky, S.I., Ivanov, V.D., Valuyskiy, M. Yu., Zueva, L.V. \& Zhukovskaya, M.I. (2018) Comparison of sensory structures on the antenna of different species of Philopotamidae (Insecta: Trichoptera). Arthropod Structure and Development, 47 , $45-55$. https://doi.org/10.1016/j.asd.2017.12.003

Morse, J.C. (2018) Trichoptera World Checklist. Available from: http://entweb.sites.clemson.edu/database/trichopt/index.htm (Accessed 9 October 2018)

Morse, J.C. \& Yang, L. (1993) Higher classification of the Chinese Glossosomatidae (Trichoptera). In: Otto, C. (Ed.), Proceedings of the 7th International Symposium on Trichoptera. Backhuys Publishers, Leiden, The Netherlands, pp. 139-148.

Nicholson, D.B., Mayhew, P.J. \& Ross, A.J. (2015) Changes to the fossil record of insects through fifteen years of discovery. PLOS ONE, 10, e 0128554. https://doi.org/10.1371/journal.pone.0128554

Newman, E. (1838) Entomological notes. Entomological Magazine, 5, 168-181.

Ross, H.H. (1956) Evolution and Classification of the Mountain Caddisflies. University of Illinois Press, Urbana, 213 pp.

Ross, H.H. (1967) The evolution and past dispersal of the Trichoptera. Annual Review of Entomology, 12, $169-206$. https://doi.org/10.1146/annurev.en.12.010167.001125

Schmid, F. (1970) 210. Trichoptera III. Ergebnisse der zoologischen Forschungen von Dr. Z. Kaszab in der Mongolei. Reichenbachia, 13, 114-124.

Scopoli, J.A. (1763) Entomologia Carniolica Exhibens Insecta Carnioliae Indigen et Distributa in Ordines, Genera, Species, Varietates, Methodo Linneana. Trattner, Vindobonae [Vienna]. https://doi.org/10.5962/bhl.title.119976

Sinitsina, E.E. \& Chaika, S.Yu. (2006) Electron Microscopy of Chemoreceptor Organs of Insects: An Atlas. Moscow State University, Moscow, 334 pp. [in Russian]

Stephens, J.F. (1834) Illustrations of British Entomology; or, a Synopsis of Indigenous Insects; Containing Their Generic and Specific Distinctions; with an Account of Their Metamorphoses, Times of Appearance, Localities, Food, and Economy, as Far as Practicable, 5. Baldwin and Cradock, London, pp. 305-368.

Sukatsheva, I.D. (1990) Caddis flies. Phryganeida. Trudy Paleontologicheskogo Instituta, 239, 94-122.

Tjeder, B. (1956) Zwei neue ost-asiatische Bittacus-Arten. Beiträge zur Entomologie, 6, 45-53.

Valuyskiy, M.Yu., Melnitsky, S.I. \& Ivanov, V.D. (2017) Structure of antennal sensilla in the caddisfly genus Rhyacophila Pictet (Trichoptera, Rhyacophilidae). Entomological Review, 97 (6), 703-722. https://doi.org/10.1134/S001387381706001X

Wallengren, H.D.J. (1891) Skandinaviens Neuroptera. Andra afdelningen. Kongliga Svenska Vetenskaps-Akademien Handlingar, 24, 1-173.

Wang, X., Zhou, Y. \& Ren, D. (2009) New fossil caddisfly from Middle Jurassic of Daohugou, Inner Mongolia, China (Trichoptera: Philopotamidae). Progress in Natural Science. 19 (10), 1427-1431. https://doi.org/10.1016/j.pnsc.2009.01.012

Wells, A. (1984) Comparative studies of antennal features of adult Hydroptilidae (Trichoptera). In: Morse, J.C. (Ed.), Proceedings of the 4th International Symposium on Trichoptera, 30. W. Junk, The Hague; Boston, pp. 423-440. 